\title{
PONGAMIA PINNATA (L.) PANIGRAHI AQUEOUS EXTRACT ALLEVIATES MERCURIC CHLORIDE INDUCED STRESS ON SEEDLING GROWTH OF MAIZE
}

\author{
Bibi, K. - MushtaQ, N. - Mahmood, S. - Ullah, F. - KhattaK, A. - Perveen, I. - Begum, K. - \\ ABBAS, S.*
}

Department of Botany, University of Science and Technology, Bannu, Pakistan

*Corresponding author

e-mail:sairaabbas07@gmail.com

(Received $13^{\text {th }}$ Feb 2018; accepted $9^{\text {th }}$ May 2018)

\begin{abstract}
Aqueous extract of Pongamia pinnata (PALE) was accessed to alleviate mercuric chloride $\left(\mathrm{HgCl}_{2}\right)$ induced stress on seed germination and early seedling growth of Zea mays L. Maize seeds were soaked in 5 and 2.5\% PALE prior to sowing in the pots and $\mathrm{HgCl}_{2}$ was applied at rate of 1 and $0.5 \mathrm{mg} \mathrm{kg}^{-}$ ${ }^{1}$ to the soil to induce an artificial stress for the germination and seedling growth. The results showed that seed germination (\%), root dry weight and photosynthetic pigments were significantly reduced by $\mathrm{HgCl}_{2}$ at $1 \mathrm{mg} \mathrm{kg}^{-1}$, which resulted in accumulation of phenolic compounds in maize leaves. It was found that the total soluble phenolic content was negatively correlated with shoot dry weight $(r=-0.656, p=0.001)$. On the other hand, seed soaked with PALE significantly alleviated adverse effects of $\mathrm{HgCl}_{2}$ stress on seed germination and growth attributes of maize, thus it was found to be effective to protect maize plants from adverse effects of mercury and can be recommended for application in mercury contaminated areas of farmer's field.
\end{abstract}

Keywords: mercury stress, phenolic, Pongamia pinnata, phytoremidiation, PALE, Zea mays, $\mathrm{HgCl}_{2}$

\section{Introduction}

The term 'heavy metal' is often used to cover a diverse range of elements, which are considered to be toxic to human health as being an important class of pollutants. Although heavy metals are naturally present in the soil (Zakir et al., 2014), but the geologic and anthropogenic activities have caused them to increase to the toxic level that are harmful to both plants and animals (Alyemeni and Almohisen, 2014). Heavy metals adversely affect the development of both vegetative and generative parts of the plants (Jeliazkova and Craker, 2003) leading to losses in yield (Chatterjee and Chatterjee, 2000). Therefore, the remediation of heavy metal polluted soils cannot be over emphasized (Chibuike and Obiora, 2014).

Heavy metals block functional groups of metabolically important molecules, alter hormonal balance, reduce nutrient assimilation, protein synthesis, and DNA replication (Nagajyoti et al., 2010). They inhibit chlorophyll synthesis by substitution of magnesium in chlorophyll and also water uptake (Boening, 2000). Among the various types of heavy metals, mercury accumulates in all parts of the plant but mostly in roots indicating that roots serve as a barrier to mercury uptake (Bibi et al., 2016).

To reclaim the soils contaminated with heavy metals, various physical and chemical approaches have been adopted but these are expensive and make the soil unsuitable for plant growth (Marques et al., 2009). Biological approach (bioremediation) on other hand is the best for establishment / reestablishment of plants on polluted soils. Being a natural process, it is an environment friendly method. Phytoremediation is a part of bioremediation in which plants are used for the treatment of polluted soils (Cuypers et 
al., 2010). The different mechanisms used for phytoremediation are phytostabilization, phytovolatilization and phytoextraction (Chaney et al., 1997). The amount of phytochemicals such as plant phenolics are reported to increase under the stress of heavy metals. This increase of phenolic content is correlated with increased activity of enzymes involved in biosynthesis of phenols under heavy metal stress (Winkel-Shirley, 2002; Rizvi, 2006; Bibi et al., 2016).

Pongamia (Millettia pinnata), formerly known as Pongamia pinnata, is a tree/shrub widely cultivated in Pakistan. It can tolerate a wide range of soil types including saline, alkaline, sandy, heavy clay and rocky soils and waterlogged soils. Pongamia is used in land reclamation and as a soil stabilizer (Shirbhate and Malode, 2012). Keeping in view the harmful effects of heavy metals on plants and the role of phytochemicals in heavy metal stress tolerance of plants, the present investigation was carried out to alleviate mercury induced stress on maize plants by Pongamia pinnata leaf extract.

\section{Material and methods}

The healthy and fully expended leaves of Pongamia pinnata $(200 \mathrm{~g})$ were collected (20 gm per tree) from the campus of the University of Science and Technology, Bannu, mixed together to form a composite sample, dried under shade for 2 to 3 weeks and finely ground in an electric grinder. The elemental composition of Pongamia Pinnata leaf was analysed following the method described by Rashid (1986). The powdered leaf material was digested in a solution of nitric acid and perchloric acid (2:1) and heated at $150{ }^{\circ} \mathrm{C}$. After cooling it to room temperature, the volume was raised to $50 \mathrm{ml}$ using deionized water and filtered. Elemental analyses were carried out using an Atomic Absorption Spectrophotometer (Model: Perkin Elmer Analyst-200, USA).

\section{Preparation of Pongamia pinnata leaf extract}

Formal maceration techniques were used in the preparation of extracts. The Pongamia pinnata leaf powder $(20 \mathrm{~g})$ was soaked in $200 \mathrm{~mL}$ of distilled water and was kept there for $48 \mathrm{~h}$. It was filtered first with fine porous cloth and then with a Whatman No. 1 filter paper. The aqueous extract obtained was designated as a $10 \%$ (w/v) stock solution. This stock solution was further diluted to 5 and $2.5 \%(\mathrm{w} / \mathrm{v})$ in distilled water and were denoted as PALE.

\section{Bioassay}

The seeds of maize (Zea mays L., variety Azam) were obtained from the Agriculture Research Centre Sara-e- Nourang, Lakki Marwat, KP, Pakistan. Finely ground uniformed soil (sand and clay 1:1) was filled in plastic pots $\left(8 \times 12 \mathrm{~cm}^{2}\right)$ for sowing of maize seeds in order to facilitate easy penetration of roots and uprooting of plants at the time of harvest. The soil used as culture medium was analyzed for $\mathrm{pH}$, content of available nitrogen and phosphorous using standard protocols. Determination of soil $\mathrm{pH}$ was carried out by the method of McLean (1982). For electrical conductivity (EC) determination, the saturated paste of soil was prepared by suspending soil into water and thoroughly mixed by using magnetic stirrer for $30 \mathrm{~min}$. After settling, the EC was noted by using conductivity meter (Page et al., 1982). Phosphorous content of the soil was determined according to the method of Olsen and Sommers (1982). For determination of total nitrogen content $10 \mathrm{~g}$ of soil was digested in micro-Kjeldahl flask 
with $20 \mathrm{~mL}$ of concentrated $\mathrm{H}_{2} \mathrm{SO}_{4}$ and $10 \mathrm{~g}$ digestion mixture. After digestion, the flasks were allowed to cool. The contents were transferred to a $50 \mathrm{~mL}$ flask and distilled. The distillation was carried out in the presence of $20 \mathrm{~mL}$ of $40 \% \mathrm{NaOH}$ and collected in $5 \mathrm{~mL}$ boric acid. The distillate was titrated against $0.1 \mathrm{~N} \mathrm{H}_{2} \mathrm{SO}_{4}$ using $\mathrm{KMNO}_{4}$ as indicator. The particle size of the soil was determined at Agriculture Research Station Sari Naurang Lakki Marwat, Pakistan. The physico-chemical properties of the soil are shown in Table 1.

Table 1. Physico-chemical properties of the soil used in the experiment

\begin{tabular}{c|c}
\hline Parameters & Values \\
\hline $\mathrm{pH}$ & 7.5 \\
\hline E.C. & $3.10 \mathrm{dS} \mathrm{m}^{-1}$ \\
\hline Total nitrogen content & $0.41 \% \mathrm{dry} \mathrm{weight}$ \\
\hline Total phosphorous content & $29 \mathrm{mg} \mathrm{kg}^{-1}$ \\
\hline Clay $(<0.002 \mathrm{~mm})$ & $34 \%$ \\
\hline Fine silt $(0.002-0.02 \mathrm{~mm})$ & $13 \%$ \\
\hline Fine sand $(0.05-0.2 \mathrm{~mm})$ & $23 \%$ \\
\hline Coarse sand $(0.2-2 \mathrm{~mm})$ & $30 \%$ \\
\hline
\end{tabular}

To impose artificial stress of mercury, $\mathrm{HgCl}_{2}$ was added at 1 and $0.5 \mathrm{mg} \mathrm{kg}^{-1}$ soil. The experiment was carried out statistically in completely randomized design (CRD) with three replications for each treatment (various levels of mercury and PALE) in a glass house in the Department of Botany, University of Science and Technology, Bannu, KP Province, Pakistan. Maize seeds were soaked in various treatment levels of PALE for three hours before sowing them in pots. The following samples were examined: Control pots where seeds soaked in distilled water were sown, Pots with soil contaminated with $\mathrm{HgCl}_{2}$ at $1 \mathrm{mg} \mathrm{kg}^{-1}$ soil, Pots with soil contaminated with $\mathrm{HgCl}_{2}$ at $0.5 \mathrm{mg} \mathrm{kg}^{-1}$ soil, Pots with soil contaminated with $\mathrm{HgCl}_{2}$ at $1 \mathrm{mg} \mathrm{kg}^{-1}$ soil where seeds soaked in 5\% PALE were sown, Pots with soil contaminated with $\mathrm{HgCl}_{2}$ at $1 \mathrm{mg} \mathrm{kg}^{-1}$ soil where seeds soaked in $2.5 \%$ PALE were sown, Pots with soil contaminated with $\mathrm{HgCl}_{2}$ at $0.5 \mathrm{mg} \mathrm{kg}^{-1}$ soil, where seeds soaked in 5\% PALE were sown, Pots with soil contaminated with $\mathrm{HgCl}_{2}$ at $0.5 \mathrm{mg} \mathrm{kg}^{-1}$ soil, where seeds soaked in $2.5 \%$ PALE were sown.

When $90 \%$ of the seeds were germinated in control pots, the seeds germination (\%) was calculated according to the following formula:

Seed germination $(\%)=($ Seeds germination $/$ Total number of seeds grown $) \times 100$

The plants were harvested 28 days after sowing and were analyzed for the following morphological, physiological and biochemical growth attributes. The shoot and root weight were determined using electronic balance. Root length was determined using a measuring tape. The leaf photosynthetic pigments were analysed according to the method described by Arnon (1949). The total soluble phenolic content of the maize leaves were determined by the Folin-Ciocalteau method (Wolfe et al., 2003). The extract $(200 \mu \mathrm{L})$ was mixed with the Folin-Ciocalteau reagent (Sigma-Aldritch, Cat \# F9252-100ML) and incubated for five minutes at room temperature in dark. The 
mixture was added to a $1.5 \mathrm{~mL}$ sodium carbonate $(7 \%, \mathrm{w} / \mathrm{v})$ solution and incubated in dark for $90 \mathrm{~min}$. The optical density of the mixture was determined at $760 \mathrm{~nm}$ using a spectrophotometer (Hitachi's U-5100 Tokyo, Japan). Standard curve made of various concentrations of gallic acid solutions was matched with the sample measurements. The concentration of total phenolic content was expressed as $\mu \mathrm{g}$ gallic acid equivalents $\mathrm{g}^{-1}$ sample.

\section{Statistical analyses}

Analysis of variance technique (ANOVA) was used for the analysis of data and the Least Significant Difference (LSD) test (Steel and Torrie, 1980) was used for the comparison of treatment means. Student Statistix (version 8.1 USA) software package was used for the determination of coefficient of correlation.

\section{Results and discussion}

The Pongamia leaf was analysed for elemental composition and total soluble phenolic content (Table 2). Among macronutrients, $\mathrm{Na}\left(204 \mu \mathrm{g} \mathrm{g}_{-}^{-1}\right), \mathrm{K}\left(197 \mu \mathrm{g} \mathrm{g}^{-1}\right), \mathrm{Ca}$ $\left(67 \mu \mathrm{g} \mathrm{g}^{-1}\right)$ and $\mathrm{Mg}\left(89 \mu \mathrm{g} \mathrm{g}^{-1}\right)$ were determined. Among micronutrients $\mathrm{Fe}(42 \mu \mathrm{g} / \mathrm{g})$, $\mathrm{Mn}(22 \mu \mathrm{g} / \mathrm{g})$ and $\mathrm{Zn}(35.22 \mu \mathrm{g} / \mathrm{g})$ were analysed. The total soluble phenolic content of Pongamia leaf was $139 \mathrm{mg}$ gallic acid $\mathrm{g}^{-1}$ d.w. Plant extracts were characterized by the presence of natural phenolics and various types of nutrients having beneficial effect on plant growth (Ullah et al., 2014; Khattak et al., 2015).

Table 2. Nutrient composition of Pongamia pinnata leaf

\begin{tabular}{c|c}
\hline Parameter studied & Value $\left(\boldsymbol{\mu g} \mathbf{g}^{-\mathbf{1}} \mathbf{d . w}\right)$ \\
\hline $\mathrm{Na}^{+}$ & 204 \\
\hline $\mathrm{K}^{+}$ & 197 \\
\hline $\mathrm{Mg}^{2+}$ & 67 \\
\hline $\mathrm{Ca}^{2+}$ & 80 \\
\hline $\mathrm{Fe}^{2+}$ & 42 \\
\hline $\mathrm{Mn}^{2+}$ & 22 \\
\hline $\mathrm{Zn}^{2+}$ & 35 \\
\hline Total soluble phenolic content $\left(\mu \mathrm{g}\right.$ gallic acid g $\left.{ }^{-1} \mathrm{~d} . \mathrm{w}\right)$ & 139000 \\
\hline
\end{tabular}

The data depicted that soil contamination with higher concentration of $\mathrm{HgCl}_{2}(1 \mathrm{mg}$ $\mathrm{kg}^{-1}$ soil) significantly reduced the seed germination compared to control (Table 3). On the other hand, seeds soaked with PALE significantly ameliorated adverse effects of $\mathrm{HgCl}_{2}$ on seed germination (\%). A negative impact of $\mathrm{HgCl}_{2}$ stress on shoot fresh and dry weights was observed (Table 3). However, the exogenous application of PALE minimized adverse effects of $\mathrm{HgCl}_{2}$ on shoot fresh and dry weights. Root length was also significantly reduced by $\mathrm{HgCl}_{2}$ at $1 \mathrm{mg} \mathrm{kg}^{-1}$ soil as compared to untreated control (Table 3). The application of PALE (5\%) exhibited stimulatory effects and minimized adverse effects of $\mathrm{HgCl}_{2}$ on root length. The soil contamination with $\mathrm{HgCl}_{2}$ significantly decreased root fresh weight as compared to control ( $\mathrm{p}<0.05)$. The PALE effectively protected fresh weight of roots from adverse effects of $\mathrm{HgCl}_{2}$ induced stress. At higher concentration of $\mathrm{HgCl}_{2}\left(1 \mathrm{mg} \mathrm{kg}^{-1}\right.$ soil), the beneficial effect of PALE on root fresh 
weight was also found to be stronger. The $\mathrm{HgCl}_{2}$ has no significant effect on root dry weight (Table 3).

Table 3. Effect of PALE on morphological growth attributes of maize under mercuric chloride stress

\begin{tabular}{|c|c|c|c|c|c|c|c|}
\hline \multicolumn{2}{|r|}{ Treatment } & \multirow{2}{*}{\begin{tabular}{|c|}
$\begin{array}{c}\text { Germination } \\
(\%)\end{array}$ \\
$\mathrm{r}$
\end{tabular}} & \multirow{2}{*}{\begin{tabular}{|c}
$\begin{array}{c}\text { Shoot } \\
\text { fresh } \\
\text { weight }(\mathrm{g})\end{array}$ \\
$1.286 \mathrm{a}$
\end{tabular}} & \multirow{2}{*}{ 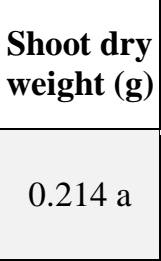 } & \multirow{2}{*}{$\begin{array}{c}\text { Root fresh } \\
\text { weight (g) }\end{array}$} & \multirow{2}{*}{\begin{tabular}{|c}
$\begin{array}{c}\text { Root dry } \\
\text { weight } \\
\text { (g) }\end{array}$ \\
$0.077 \mathrm{ab}$
\end{tabular}} & \multirow{2}{*}{$\begin{array}{c}\begin{array}{c}\text { Root } \\
\text { length } \\
(\mathbf{c m})\end{array} \\
68.22 \mathrm{ab}\end{array}$} \\
\hline T0 & $\begin{array}{l}\text { Control (pots where seeds } \\
\text { soaked in distilled water } \\
\text { were sown) }\end{array}$ & & & & & & \\
\hline $\mathrm{T} 1$ & $\begin{array}{l}\text { Pots with soil contaminated } \\
\text { with } \mathbf{H g C l}_{\mathbf{2}} \text { at } \mathbf{1} \mathbf{~ m g ~ k g}^{-1} \text { soil }\end{array}$ & $83.2 \mathrm{~b}$ & $0.440 \mathrm{c}$ & $0.013 \mathrm{c}$ & $0.420 \mathrm{~d}$ & $0.057 \mathrm{ab}$ & $53.42 \mathrm{~d}$ \\
\hline $\mathrm{T} 2$ & $\begin{array}{l}\text { Pots with soil contaminated } \\
\text { with } \mathbf{H g C l}_{\mathbf{2}} \mathbf{0 . 5} \mathbf{~ m g ~ k g}^{-1} \text { soil }\end{array}$ & $99.4 \mathrm{a}$ & $0.905 \mathrm{ab}$ & $0.096 \mathrm{bc}$ & $0.440 \mathrm{~cd}$ & $0.112 \mathrm{a}$ & $63.05 \mathrm{bc}$ \\
\hline $\mathrm{T} 3$ & $\begin{array}{llll}\text { Pots with soil contaminated } \\
\text { with } & \mathbf{H g C l}_{\mathbf{2}} \mathbf{1} \mathbf{~ m g ~}_{\mathbf{~ k g}}^{-\mathbf{1}} & \text { soil } \\
\text { and seeds soaked in } & \mathbf{5 \%} \\
\text { PALE were sown } & \end{array}$ & $100.0 \mathrm{a}$ & $0.873 \mathrm{~b}$ & $0.137 \mathrm{ab}$ & $0.603 \mathrm{bc}$ & $0.064 \mathrm{ab}$ & $72.22 \mathrm{a}$ \\
\hline $\mathrm{T} 4$ & $\begin{array}{l}\text { Pots with soil contaminated } \\
\text { with } \mathbf{H g C l}_{2} \mathbf{1} \mathbf{~ m g ~ k g}^{-1} \text { soil } \\
\text { and seeds soaked in } \mathbf{2 . 5 \%} \\
\text { PALE were sown }\end{array}$ & $94.4 \mathrm{a}$ & $0.817 \mathrm{bc}$ & $0.141 \mathrm{ab}$ & $0.534 \mathrm{~cd}$ & $0.062 \mathrm{ab}$ & $57.75 \mathrm{~cd}$ \\
\hline T5 & $\begin{array}{l}\text { Pots with soil contaminated } \\
\text { with } \mathbf{H g C l}_{\mathbf{2}} \mathbf{0 . 5} \mathbf{~ m g ~ k g}^{-1} \text { soil } \\
\text { and seeds soaked in } \mathbf{5 \%} \\
\text { PALE were sown }\end{array}$ & $94.4 \mathrm{a}$ & $0.910 \mathrm{ab}$ & $0.095 \mathrm{bc}$ & $0.743 \mathrm{ab}$ & $0.048 \mathrm{ab}$ & $65.49 \mathrm{abc}$ \\
\hline T6 & $\begin{array}{l}\text { Pots with soil contaminated } \\
\text { with } \mathbf{H g C l}_{\mathbf{2}} \mathbf{0 . 5} \mathbf{~ m g ~ k g}^{-1} \text { soil } \\
\text { and seeds soaked in } \mathbf{2 . 5 \%} \\
\text { PALE were sown }\end{array}$ & $100.0 \mathrm{a}$ & $0.941 \mathrm{ab}$ & $0.140 \mathrm{~b}$ & $0.730 \mathrm{ab}$ & $0.042 \mathrm{~b}$ & $71.70 \mathrm{ab}$ \\
\hline & LSD & 9.03 & 0.400 & 0.0875 & 0.1659 & 0.0697 & 8.86 \\
\hline
\end{tabular}

Means sharing common English letters are statistically similar $(p=0.05, \mathrm{n}=3)$

Mercury stress results in abnormal seed germination with a significant reduction in germination indices (Patra and Sharma, 2000). Mercury reduces mitotic activity in plant organs, therefore results in lower biomass production (Patra et al., 2004). The beneficial effect of PALE on seed germination and morphological growth characters of maize under $\mathrm{HgCl}_{2}$ could be attributed to its phytochemical composition. Previous studies have shown that the aqueous leaf extract of Moringaoleifera was highly effective and protected maize plants from adverse effect of $\mathrm{HgCl}_{2}$ (Bibi et al., 2016).

Results showed that $\mathrm{HgCl}_{2}$ at $1 \mathrm{mg} \mathrm{kg}^{-1}$ soil significantly reduced chlorophyll $a$ content as compared to control (Table 4). The application of PALE at 5\% concentration significantly ameliorated adverse effects of $\mathrm{HgCl}_{2}$ stress on chlorophyll $a$ content. All the treatments showed non-significant effect on chlorophyll $b$ content (Table 4). The reduction of chlorophyll content under mercury stress has been reported in Marrabiumvulgare (Moreno-Jiménez et al., 2007). Mercury disrupts the photosynthetic machinery by inactivating the magnesium ion of the chlorophyll molecule (Patra et al., 2004). 
Table 4. The effect of PALE on physiological attributes of maize under mercuric chloride stress

\begin{tabular}{|c|c|c|c|c|}
\hline \multicolumn{2}{|r|}{ Treatment } & \multirow{2}{*}{$\begin{array}{c}\text { Chl } \boldsymbol{a}(\mathbf{m g} / \mathbf{g} \text { f.w) } \\
12.88 \mathrm{a}\end{array}$} & \multirow{2}{*}{\begin{tabular}{|c} 
Chl $\boldsymbol{b}$ (mg/g f.w) \\
$6.224 \mathrm{a}$
\end{tabular}} & \multirow{2}{*}{\begin{tabular}{|c|}
$\begin{array}{c}\text { Total soluble phenolic } \\
\text { content (mg gallic acid } \\
\text { eq./g f.w) }\end{array}$ \\
$34.94 \mathrm{c}$
\end{tabular}} \\
\hline T0 & $\begin{array}{l}\text { Control (pots where seeds soaked in } \\
\text { distilled water were sown) }\end{array}$ & & & \\
\hline $\mathrm{T} 1$ & $\begin{array}{l}\text { Pots with soil contaminated with } \\
\mathbf{H g C l}_{\mathbf{2}} \text { at } \mathbf{1} \mathbf{~ m g ~ k g ~}^{-1} \text { soil }\end{array}$ & $4.98 \mathrm{c}$ & $3.665 \mathrm{~b}$ & $64.52 \mathrm{~b}$ \\
\hline $\mathrm{T} 2$ & $\begin{array}{l}\text { Pots with soil contaminated with } \\
\mathbf{H g C l}_{\mathbf{2}} \mathbf{0 . 5} \mathbf{~ m g ~ k g}^{-1} \text { soil }\end{array}$ & $11.66 \mathrm{ab}$ & $4.667 \mathrm{ab}$ & $45.46 \mathrm{c}$ \\
\hline $\mathrm{T} 3$ & $\mid \begin{array}{l}\text { Pots with soil contaminated with } \\
\mathbf{H g C l}_{2} \mathbf{1} \mathbf{~ m g ~}_{\mathbf{~ k g}^{-1}} \text { soil and seeds } \\
\text { soaked in } \mathbf{5 \%} \text { PALE were sown }\end{array}$ & $12.54 \mathrm{a}$ & $7.120 \mathrm{a}$ & $106.88 \mathrm{a}$ \\
\hline $\mathrm{T} 4$ & $\left|\begin{array}{l}\text { Pots with soil contaminated with } \\
\mathbf{H g C l}_{2} \mathbf{1} \mathbf{~ m g ~ k g}^{-1} \text { soil and seeds } \\
\text { soaked in } \mathbf{2 . 5 \%} \text { PALE were sown }\end{array}\right|$ & $10.37 \mathrm{~b}$ & $6.443 \mathrm{a}$ & $105.15 \mathrm{a}$ \\
\hline $\mathrm{T} 5$ & $\left|\begin{array}{l}\text { Pots with soil contaminated with } \\
\mathbf{H g C l}_{2} \mathbf{0 . 5} \mathbf{~ m g ~ k g}^{-1} \text { soil and seeds } \\
\text { soaked in } \mathbf{5 \%} \text { PALE were sown }\end{array}\right|$ & $13.19 \mathrm{a}$ & $6.637 \mathrm{a}$ & $67.10 \mathrm{~b}$ \\
\hline T6 & $\left|\begin{array}{l}\text { Pots with soil contaminated with } \\
\mathbf{H g C l}_{\mathbf{2}} \mathbf{0 . 5} \mathbf{~ m g ~ k g}^{-1} \text { soil and seeds } \\
\text { soaked in } \mathbf{2 . 5 \%} \text { PALE were sown }\end{array}\right|$ & $10.24 \mathrm{~b}$ & $5.063 \mathrm{ab}$ & $49.41 \mathrm{bc}$ \\
\hline & LSD & 2.025 & 2.502 & 17.803 \\
\hline
\end{tabular}

Means sharing common English letters are statistically similar $(p=0.05, \mathrm{n}=3)$

In the present investigation, it was found that $\mathrm{HgCl}_{2}$ induced stress caused accumulation of phenolic compounds in the leaves of maize (Table 4). Total soluble phenolic content was found to be higher when $\mathrm{HgCl}_{2}$ was applied at $1 \mathrm{mg} \mathrm{kg}^{-1}$ soil. However, soaking seeds in PALE resulted in further augmented accumulation of phenolics in maize leaves. The most effective concentration of PALE was 5\%. Plants accumulate phenolic compounds when exposed to heavy metal stress (Klepacka et al., 2011). Accumulation of phenolic under heavy metal stress has also been reported in Phaseolus vulgaris (Hamid et al., 2010), Boerhavia diffusa (Abdussalam et al., 2015) and Trigonellafoenum-graecum (Askari and Azmat, 2013). Phenolic compounds protect cell biomolecules from oxidative damage by scavenging reactive oxygen species and prevent lipid peroxidation. This is achieved by the reduced forms of phenolic compounds whereas in oxidized state, these may function as prooxidants (Sakihama et al., 2000). Antioxidant activity of Pongamia extract was correlated with its flavonoid and phenol content (Behera et al., 2012). The higher increase in phenolic compounds by seed soaked with PALE under $\mathrm{HgCl}_{2}$ stress indicates the possible role of bioactive compounds present in the extract which contributed to the mercury stress tolerance of maize.

It was observed that $\mathrm{Hg}$ stress resulted in the accumulation of phenolic compounds with a reduction in the content of photosynthetic pigments. On the other hand PALE not only caused accumulation of phenolic compounds but also improved the content of photosynthetic pigments. This suggested that exogenous application of PALE reduced chlorophyllase activity responsible for chlorophyll degradation. Phenolic compounds 
either stimulate or inhibit the content of photosynthetic pigments that is why phenolics are considered as compounds with bifunctional role, one of stimulation and another of inhibition (Yang et al., 2004). This may be attributed to the fact that phytochemicals present in PALE have stimulatory effect on photosynthetic pigments in maize.

The correlation of chlorophyll $a$ was found to be positive with chlorophyll $b$ $(\mathrm{r}=0.691, \mathrm{p}=0.000)$, germination $(\%)(\mathrm{r}=0.581, \mathrm{p}=0.005)$, root fresh weight $(\mathrm{r}=0486, \mathrm{p}=0.025)$ and shoot fresh weight $(\mathrm{r}=0.571, \mathrm{p}=0.006)$. The total soluble phenolic content was negatively correlated with shoot dry weight $(r=-0.656$, $\mathrm{p}=0.001$ ). The correlation of root fresh weight was also positive with shoot fresh weight $(r=0.491, p=0.023)$.

\section{Conclusion}

The growth of maize was inhibited when grown on $\mathrm{HgCl}_{2}$ contaminated soil due to the toxicity of mercury. This mercury stress was associated with the accumulation of phenolic compounds. It was found in the present studies that exogenous application of PALE was effective in alleviating the adverse effects of $\mathrm{HgCl}_{2}$ on maize plants grown under $\mathrm{HgCl}_{2}$ contaminated areas, thus, PALE can be used in bioremediation of contaminated soils for better plant growth. Pongamia pinnata is a drought tolerant and nitrogen fixing plant species. Its oil has potential for use as a feedstock for biodiesel production and can survive under harsh environmental conditions. Therefore, it is a more suitable tree species for exploitation as a source of future bioregulators for improving growth and productivity of crop plants.

\section{REFERENCES}

[1] Abdussalam, A., Ravindran, C., Ratheesh, C. P., Azeez, K., Nabeesa, S. (2015): Physiological effects of heavy metal toxicity and associated histological changes in boerhavia diffusa 1. - J Global Biosci 4(1): 1221-1234.

[2] Alyemeni, M. N., Almohisen, I. A. (2014): Traffic and industrial activities around Riyadh cause the accumulation of heavy metals in legumes: A case study. - Saudi J Biol Sci 21(2): 167-172.

[3] Arnon, D. I. (1949): Copper enzymes in isolated chloroplasts. Polyphenoloxidase in Beta vulgaris. - Plant Physiology 24(1): 1.

[4] Askari, S., Azmat, R. (2013): Biosorption of Hg: Ii. Repairing of epidermal layer of leaves through nutrients of seaweeds in $\mathrm{Hg}$ distorted seedlings of cicer arietinum. - Pak J Bot 45: 1721-1727.

[5] Behera, S., Babu, S. M., Ramani, Y. R., Choudhury, P. K. (2012): Studies on hepatoprotective activity of hydroalcoholic leaf extract of pongamia pinnata against $\mathrm{i} / \mathrm{r}$ induced hepatic reperfusion injury. - IJPBS 2(3): 15-30.

[6] Bibi, A., Ullah, F., Mehmood, S., Bibi, K., Khan, S. U., Khattak, A., Ullah Khan, R. (2016): Moringa oleifera lam. Leaf extract as bioregulator for improving growth of maize under mercuric chloride stress. - Acta Agriculturae Scandinavica, Section B-Soil \& Plant Science 66(6): 469-475.

[7] Boening, D. W. (2000): Ecological effects, transport, and fate of mercury: A general review. - Chemosphere 40(12): 1335-1351.

[8] Chaney, R. L., Malik, M., Li, Y. M., Brown, S. L., Brewer, E. P., Angle, J. S., Baker, A. J. (1997): Phytoremediation of soil metals. - Curr Opinion Biotechnol 8(3): 279-284.

[9] Chatterjee, J., Chatterjee, C. (2000): Phytotoxicity of cobalt, chromium and copper in cauliflower. - Environ Poll 109(1): 69-74. 
[10] Chibuike, G., Obiora, S. (2014): Heavy metal polluted soils: Effect on plants and bioremediation methods. - Appl Environ Soil Sci 2014: 12. DOI: http://dx.doi.org/10.1155/2014/752708.

[11] Cuypers, A., Plusquin, M., Remans, T., Jozefczak, M., Keunen, E., Gielen, H., Opdenakker, K., Nair, A. R., Munters, E., Artois, T. J. (2010): Cadmium stress: An oxidative challenge. - Biometals 23(5): 927-940.

[12] Hamid, N., Bukhari, N., Jawaid, F. (2010): Physiological responses of phaseolus vulgaris to different lead concentrations. - Pak J Bot 42(1): 239-246.

[13] Jeliazkova, E., Craker, L. (2003): Seed germination of some medicinal and aromatic plants in heavy metal environment. - J Herbs Spices Med Plants 10(2): 105-112.

[14] Khattak, A., Ullah, F., Wazir, S. M., Shinwari, Z. K. (2015): Allelopathic potential of jatropha curcas 1 . Leaf aqueous extracts on seedling growth of wheat. - Pak J Bot 47(6): 2449-2454.

[15] Klepacka, J., Gujska, E., Michalak, J. (2011): Phenolic compounds as cultivar-and variety-distinguishing factors in some plant products. - Plant Foods Human Nutr 66(1): 64-69.

[16] Marques, A. P., Rangel, A. O., Castro, P. M. (2009): Remediation of heavy metal contaminated soils: Phytoremediation as a potentially promising clean-up technology. Crit Rev Environ Sci Technol 39(8): 622-654.

[17] McLean, E. (1982): Soil pH and Lime Requirement. - American Society of Agronomy, Soil Science Society of America, Madison, WI, USA.

[18] Moreno-Jiménez, E., Peñalosa, J. M., Esteban, E., Carpena-Ruiz, R. O. (2007): Mercury accumulation and resistance to mercury stress in rumex induratus and marrubium vulgare grown in perlite. - J Plant Nutr Soil Sci 170(4): 485-494.

[19] Nagajyoti, P., Lee, K., Sreekanth, T. (2010): Heavy metals, occurrence and toxicity for plants: A review. - Environ Chem Lett 8(3): 199-216.

[20] Olsen, S., Sommers, L. (1982): Phosphorus. - In: Page, A. et al. (eds.) Methods of Soil Analysis. Part 2. Agron. Monogr. 9, pp. 403-430. ASA and SSSA.

[21] Page, A., Miller, R., Keeney, D. (1982): Methods of Soil Analysis. Part 2. Chemical and Microbiological Properties. - American Society of Agronomy, Soil Science Society of America, Madison, WI.

[22] Patra, M., Bhowmik, N., Bandopadhyay, B., Sharma, A. (2004): Comparison of mercury, lead and arsenic with respect to genotoxic effects on plant systems and the development of genetic tolerance. - Environmental and Experimental Botany 52(3): 199-223. DOI: 10.1016/j.envexpbot.2004.02.009.

[23] Patra, M., Sharma, A. (2000): Mercury toxicity in plants. - Botanical Review 66(3): 379422. DOI: $10.1007 / \mathrm{bf02868923.}$

[24] Rashid, A. (1986): Mapping zinc fertility of soils using indicator plants and soil analyses. - Ph. D. Dissertation, pp: 199-223. Environ Exp Botany. University of Hawaii. HI, USA.

[25] Rizvi, S. I. (2006): Protection of lipid peroxidation and carbonyl formation in proteins by capsaicin in human erythrocytes subjected to oxidative stress. - Phytotherapy Res 20(4): 303-306.

[26] Sakihama, Y., Mano, J. i., Sano, S., Asada, K., Yamasaki, H. (2000): Reduction of phenoxyl radicals mediated by monodehydroascorbate reductase. - Biochem Biophys Res Commun 279(3): 949-954.

[27] Shirbhate, N., Malode, S. (2012): Heavy metals phytoremediation by pongamia pinnata (l) growing in contaminated soil from municipal solid waste landfills and compost sukali depot, amravati (ms). - Int J Adv Biotechnol Res 2(1): 147-152.

[28] Steel, R., Torrie, J. (1980): Principle and Procedures of Statistics. 2nd ed. - McGraw Hill, New York.

[29] Ullah, F., Ullah, A., Wazir, S. M., Shinwari, Z. K., Muhammad, A. (2014): Phytotoxic effects of safflower yellow exposure on seed germination and early seedling growth of canola (brassica napus 1.). - Pak J Bot 46(5): 1741-1746. 
[30] Winkel-Shirley, B. (2002): Biosynthesis of flavonoids and effects of stress. - Curr Opinion Plant Biol 5(3): 218-223.

[31] Wolfe, K., Wu, X., Liu, R. H. (2003): Antioxidant activity of apple peels. - J Agr Food Chem 51(3): 609-614.

[32] Yang, C.-M., Chang, F., Lin, S.-J., Chou, C.-H. (2004): Effects of three allelopathic phenolics on chlorophyll accumulation of rice (Oryza sativa) seedlings: Ii. Stimulation of consumption-orientation. - Botanical Bulletin of Academia Sinica 45: 119-125.

[33] Zakir, H., Sultana, N., Akter, M. (2014): Heavy metal contamination in roadside soils and grasses: A case study from Dhaka City, Bangladesh. - J Chem Biol Phys Sci 4(2): 1661. 